\title{
MUNICIPAL LEGISLATIVE BARRIERS TO A FREE MARKET
}

\author{
JoHN A. MCINTIRE* \\ Charles S. Rhyne†
}

Municipal ordinances having the possible effect of restricting a free market are more voluminous than any other single type of barrier legislation. The more than 7,000 municipalities in the United States, not to mention other local subdivisions of states possessing a measure of legislative power, have all adopted ordinances which intentionally or unintentionally operate in one way or another as barriers to the unfettered economic operation of the market within their areas. This vast volume of local legislation certainly calls for consideration aside from its counterparts in state and federal laws. The term barrier in this context is descriptive of a broad result only, and is not used in the sense of evaluating the legislation as desirable or undesirable. Throughout this discussion there will be no attempt made to determine as a matter of political philosophy or economic policy what types of local ordinances may be regarded as justified or unjustified. Regardless, however, of its merits, there are certain fundamental principles relating to the power of municipal corporations to which legislation of this type must conform if it is to be sustained by the courts. Many of these principles constitute Achilles' heels by which ordinances that are considered undesirable can be legally attacked.

The history of local ordinances relating to economic affairs traces from the earliest of municipal legislative activities. ${ }^{1}$ Even in the Middle Ages some of the principal activities of municipal authorities dealt with efforts to control matters of trade and industry, particularly with respect to importing and exporting, matters of

- A.B., 1928, Wittenberg College; LL.B., I93I, University of Cincinnati; Research Fellow, Harvard Law School, 1935-1936. Member, Ohio, United States Court of Appeals of the District of Columbia, and United States Supreme Court Bars. Associate Professor of Law, George Washington University; Faculty Editor-in-Chief, Geonge Wastnngton LAw Review. Formerly, Executive Director, National Institute of Municipal Law Officers, and Editor, Municipal LAw Journal, 1937-1941. Consultant to the National Institute of Municipal Law Officers; International Association of City Managers. Co-author (with C. W. Tooke), Cases on Municipal Corporations (I94I); articles on municipal law and government corporations in various periodicals.

†Duke University, 1928-r929, 1932-1935; LL.B., 1937, George Washington University. Member, District of Columbia and United States Supreme Court Bars. Executive Director, National Institute of Municipal Law Officers; Editor, Municipal Law Journal. Formerly, Attorney, National Institute of Municipal Law Officers, and Associate Editor, Municipal Law Journal, 1937-1941. Author, Cival AERonautics ACT ANNotated (1939); articles on aviation law in various periodicals.

${ }^{1}$ The Case of the City of London, [1610] $8 \mathrm{Co}$. Rep. I2I b, 77 Eng. Rep. 658. See also for discussion of prescriptive power to exact license fees for weighing cheese in the City of London, City of London v. Thomas Perkins, [1734] 3 Brown P. C. 602. 
competition, control of price, quality, etc. In many by-laws the admitted and avowed purpose was to control competition in favor of the local inhabitants. ${ }^{2}$ The establishment and regulation of public markets, a power of cities having its roots in the earliest organized societies, was one of the early functions of the English borough.

While the sphere of economic regulation is not at all a new topic for the consideration of municipal legislative bodies, the scope and volume of local laws of this character is constantly increasing. Investigation of many building codes reveals that their specifications operate as barriers to the use of particular types of materials or particular merchandising methods. For instance, the code standard for the thickness of plaster lathe as an element in fireproof construction may be so designed as in effect to exclude the use of metal lathe. Provisions of the Chicago building codes restrict the use of such lumber substitutes as hardboard and insulation board. These limitations are accomplished by specifying the products which are satisfactory under the fire laws instead of admitting any product which meets a specific fire test. Because of different construction principles employed in the prefabrication of dwellings, building codes will often, in effect if not by design, impede the use of this new type of construction. ${ }^{3}$ The specific content or administrative operation of many of the existing municipal electrical codes, plumbing codes, etc., also furnish examples of provisions accidentally or purposely preferring one kind of equipment or method of distribution over another. ${ }^{4}$ It has been pointed out that the plumbing code of a Pennsylvania city requires all registered plumbers to pay a fee of one dollar a fixture for every installation. Every non-resident plumber, wishing to work in the city, must register with the Board of Health and pay a registration fee of $\$ 25-\$ 50$ for each job to be performed in the city. There is some indication of a trend at the present time toward promulgation under local police power of general codes reg. ulating particularly local service occupations. ${ }^{5}$

In St. Louis, Missouri, and Dayton, Ohio, sticker ordinances have operated as effective deterrents to the sale of plumbing fixtures by mail-order houses. These ordinances provide in general that in order to secure inspection approval, all plumbing fixtures installed must have affixed a sticker secured from the city. The firm selling the fixtures must also make a report indicating the place of installation of every piece of equipment which it sells. ${ }^{6}$ This requirement is little more than a

${ }^{2}$ I McQuillin, Municipal Corporations (2d ed. 1928) \$65; i id. (rev. ed. 1940) \$941.

${ }^{8}$ See State ex rel. v. Yoter, 65 Ohio App. 492, 30 N. E. (2d) 558 (1939); sec also Matill v. City of Chattanooga, 132 S. W. (2d) 201 (Tenn. 1940).

'In the building trades investigation of the United States Department of Justice, numerous instances of "barriers" in favor of local dealers and labor have been uncovered. Dcan, Some Problems Arising in the Enforcement of the Anti-Trust Laws, in Municipalities aNd THE Law IN Action (Nat. Inst. Mun. Law Offcers, 1939) 273-280.

${ }^{5}$ Report of Committee on Social and Economic Regulation of Industry, in MUNicipalities and THE LAw in Action (Nat. Inst. of Mun. Law Officers, 1940).

- Address of Corwin Edwards, Restraints in Building Codes, Central Housing Discussion Papers : G : 1940 Series. Sce Dayton, Ohio ordinances No. 14939 and No. 15052, litigated in Dayton v. Bohachek, 26 Ohio L. Abs. $4^{17}$ (Ohio App. 1938); Direct Plumbing Supply Co. v. Dayton, Ohio Common Pleas, Montgomery County, No. 88186, 1940 (unreported). 
time-consuming irritation for the local plumbing trade, but represents a major difficulty to the doing of business by a mail-order house. The Green River type ordinance, prohibiting house-to-house canvassing without the consent of the individual householder, is perhaps the most drastic local regulation directed at a particular method of doing business.7 Municipal chain store taxes are also well-known examples of this situation. Recently, in New Jersey as well as elsewhere, local merchants demanded municipal legislative protection against the supermarkets which are a common phenomenon in every city. ${ }^{8}$

Product favoritism in Seattle took the form of legislative aid to liquid as against solid fuel. In Chicago, milk control legislation has even been directed against the use of paper containers in favor of the use of the standard glass bottle.? Many ordinances, ostensibly adopted for the purpose of protecting the local public health by requiring inspection of the milk supply, have had an extraterritorial operation which discriminates against non-residents. ${ }^{10}$ Furthermore, taxes or regulations affecting not only hawkers and peddlers, and more recently solicitors and canvassers, but also such businesses as bakeries, barber shops, beauty parlors, food stores, amusement facilities, cleaners and dyers, dairies and mill distributors, clothing and department stores, and other occupations and industries, may actually be designed to operate to the advantage of local concerns as against non-resident competitors.

Ordinances of market-barrier significance may thus operate either geographically, in an attempt to grant a preference to the local market, or non-geographically, in an attempt to discriminate in favor of one commodity, method of doing business, or class of dealers. Inasmuch as a systematic survey throughout the whole United States of all local codes and ordinances operating as municipal market barriers is impractical, the study here presented makes no pretense of such comprehensive treatment. ${ }^{11}$ Enough has been indicated, however, to illustrate the scope of local ordinances that may have the effect of impeding the ordinary economic operation of local markets. Further instances will appear in the ensuing discussion, and can also be found in other articles in this symposium.

Although no position is here taken with respect to the justification or desirability of any particular ordinances operating as market barriers, nevertheless it will perhaps be useful to suggest both sides of the picture from the local point of view. On

T Town of Green River v. Bunger, 50 Wyo. 52, 58 P. (2d) 456 (I936); Green River v. Fuller Brush Co., 65 F. (2d) $x 12$ (C. C. A. roth, 1933). Local legislation in two New York cities has been directed against peddling in a particular business. People v. Kuc, 272 N. Y. 72, 4 N. E. (2d) 939 (1936) (newspaper); Dugan Bros v. City of New York, 7 N. Y. S. (2d) 162 (1938) (bakery products). Both ordinances were invalidated.

${ }^{8}$ See the ordinance of the City of Camden, New Jersey, set forth in Great A\&P Tea Co. v. Board of Comm'rs of Camden, 4 A. (2d) 16 (N. J. 1939).

${ }^{\circ}$ Fieldcrest Dairies, Inc. v. City of Chicago, 35 F. Supp. 45 I (N. D. Ill. I940); Ex-Cell-O Corp. v. City of Chicago, 115 F. (2d) 627 (C. C. A. 7th, 1940).

${ }^{10}$ Sec, c.g., City of Rockford v. Hey, 366 Ill. 526, 9 N. E. (2d) 317 (I937); (I938) 36 Mrck. L. REv. 850 .

${ }^{11}$ Sikes and Parrish, Municipal Trade Barriers (1940) 16 IND. L. J. 220 and Note (1940) id. 247, attempt a comprehensive analysis of Indiana ordinances. 
the one hand, market-barrier legislation may be condemned as an evil tending toward creation of unfair discrimination with respect to areas or products and tending toward disruption of national economic unity. On the other hand, a good case can be made out for justifying some legislation of this type. Out-of-city or non-resident dealers entering the local market area receive the benefit of local protection of the market and enjoy the benefit of many local municipal services without in either case contributing any quid pro quo to the local treasury. ${ }^{12}$ The resident dealers with whom they compete under the resulting advantageous conditions naturally demand some equalizing factor to offset the local burdens incumbent upon them.

In addition there are other circumstances in which a regulation designed to set up a protective barrier around a local market area may, from one point of view, be entirely justified. One example of this is the following actual problem which confronted a small Missouri town about three years ago. The local used-car market was being demoralized by certain dealers from the nearby large metropolitan areas who would ship large quantities of used cars into the town for sale at cut-throat prices. The business methods employed were also questionable; the out-of-the-city concern would send large quantities of cars on consignment to an unknown and irresponsible dealer who would rent temporary quarters and might abandon the business overnight, leaving little or no trace as to his whereabouts. The local usedcar dealers suffering from the effects of this competition demanded municipal legislation in their interest. Clearly, no legislation in the form of an anti-dumping law could properly or effectively be adopted which would have the open and avowed purpose of prohibiting this practice. Nor would the imposition of a larger fee for a non-resident dealer be a valid solution. The device suggested was the use of the local power to protect the public from fraud in business transactions. As an incident of the police power the local city council had authority to prescribe reasonable regulations designed to insure that the purchaser of a used car was not getting a stolen vehicle. In order to defray the cost of investigation of used cars offered for sale, a nominal license fee could be charged. It is also arguable that it would have been reasonable to have required the dealers to register with the local authorities any used car brought in for sale from outside the local area and to withhold any sale of such cars for a short period of time in order to permit a police check on the documents of title. The small profit differential and the temporary character of the business of the consignment-sale dealer were such that the nuisance of these rather minor regulations was sufficient to discourage the offending business practice and to reach the desired result. ${ }^{13}$

\footnotetext{
${ }^{18}$ The New York City sales tax cases are a recognition of the liability of non-residents to pay a share of the cost of local government in the face of the long claimed "immunity" of non-residents from "ocal tax burdens under the commerce clause. See Chanler, The Commerce Clause and Mutricipal raxation, in Municiphlities and the LAw in Action (Nat. Inst. Mun. Law Officers, T940).

${ }^{13}$ National Institute of Municipal Law Officers, Report No. 30, Opinion Bull. No. 3 (1937). Cf. State v. Ernst, 297 N. W. 24 (Minn. 194r), holding invalid as discriminatory against non-residents a statute which required a bond and $\$ 5$ fee for all used cars brought into the state; Motor Trading Co. v. Ingels, r ro P. (2d) I32 (Cal. App. I94I), holding similarly with respect to an analogous statute.
} 
Legal justification for local taxation is the power derived from the state by an express constitutional or statutory authority to raise revenue. The fundamental basis for local exercise of regulatory authority over economic matters, however, is the police power to protect the public from fraud and dishonest practices. Local, like state, power to regulate business has been for some time restricted to a direct relation to the protection of health, morals, or safety, or to general regulation of business affected with the public interest. Since the case of Nebbia v. People of New York, ${ }^{14}$ the permissible scope of state and local economic regulation of industry has been much expanded..$^{15}$ Thus local police power has been recognized as extending to regulation of unfair competition, and even to combinations in restraint of trade. ${ }^{16}$ While municipal legislation may be considered together with state legislation of a comparable nature for application of the common tests of constitutionality, local laws are subjected to additional judicial scrutiny in view of the limited powers of cities, territorially and otherwise, and of the authority of the courts to pass upon the reasonableness of ordinances as exertions of delegated powers. ${ }^{17}$ Because of the definite limits to municipal authority, in passing upon the validity of local ordinances courts determine the scope of the charter power possessed by the local authority, whether that power has been properly pursued, whether the matter regulated is one of local as distinguished from state concern, and whether there is inconsistency with state law. And while the motives of neither local nor state legislative bodies may be inquired into in determining the legality of legislation, nevertheless the broad scope of local ordinances enacted pursuant to implied powers affords room for a rather broad consideration of the general economic effect and justification of restrictive legislation. ${ }^{18}$

The following discussion of legal problems receiving the attention of the courts with respect to barrier legislation is believed to be representative of the whole situation. Acquaintance with these problems, it should be frankly stated, is based on the writers' personal day-to-day contact with and observation of such ordinances, and the questions presented to city attorneys for litigation or for the advice of city administrators and councilmen faced with the reasonable or unreasonable legislative demands of interested groups. Although representative of but a small segment of the whole, a great many problems are presented to the courts each year requiring a consideration of the principles involved in the legality of such local ordinances as have a barrier effect.

Altogether these principles number five: first, the relation of the ordinance to the police or revenue powers; second, the reasonableness of the ordinance and the extent of judicial inquiry into economic factors in this connection; third, the effect of the ordinance on interstate commerce; fourth, the effect of the ordi-

\footnotetext{
14 29I U. S. 502 (1934).

${ }^{15}$ Kelly-Sullivan, Inc. v. Moss, 22 N. Y. S. (2d) 491 (I940), noted (I940) 9 Geo. WAsh. L. Rev, 242.

${ }^{17}$ Dilzon, Municipal Corporations (5th ed. Igri) $\$ 600$.

${ }^{28}$ Yick Wo v. Hopkins, I18 U. S. 356 (1886); LeFeber v. West Allis, rig Wis. 608, 97 N. W. 203 (Ig03).
} 
nance as to non-residents; fifth, the effect of the ordinance with respect to extraterritorial operation. In addition, the application of the privileges and immunities clauses of state and federal constitution may be involved..$^{10}$ Fundamentally, all local legislation of this type relates to some phase of either of two basic municipal powers, namely: police and revenue. The revenue measures adopted for the purpose of raising funds may have a more important incidental regulatory effect, but nevertheless, as revenue measures, they must be justified under the constitutional or the express legislative authority to tax. Police legislation is directly designed to regulate individual conduct and may relate to either express or implied power. Regulatory measures may involve license fees which sometimes resemble revenue exactions, but they must, as distinguished from taxes, bear a reasonable relation to the cost of the police power regulation involved. ${ }^{20}$ If the collections from the regulatory license fees grossly exceed that cost, the court may declare that the actual intent is revenueproducing and the measure will accordingly be held invalid in the absence of the power to tax.

The problem thus raised as to the source of the municipal power exercised in a given instance is illustrated by two recently litigated cases. A Los Angeles ordinance attempting to tax department stores was held to be based on a classification too indefinite for the purpose of taxation, ${ }^{21}$ while an ordinance imposing a $\$ 25$ license tax by the City of Seattle on each dealer in solid fuel plus a $\$ 15$ fee for each fuel truck used in excess of one was invalidated as a discrimination between solid fuel and liquid fuel dealers. ${ }^{22}$ The Seattle solid fuel tax measure was claimed by the municipal authorities to be levied as a police regulatory measure and therefore not required to be based on the same kind of classification that would be required for a revenue measure. This distinction was held immaterial in that case, but it has been treated as significant in many instances.

While there are innumerable examples of local regulatory measures which operate as market barriers through non-geographic discriminations, the problem is one for the legislature, unless the measure can be established as arbitrary or capricious

\footnotetext{
${ }^{19}$ Since the case of Robbins v. Shelby Taxing District, I20 U. S. 489 (1886), the privileges and immunities clause has been of practically no importance in federal court decisions in this connection. This is not correspondingly true of state litigation, however. Cf. New York v. Roberts, 17r U. S. 658 (1898), and State v. Cohen, 133 Me. 293, 177 Atl. 403 (1935). Since the decision in the New York City sales tax case, however, McGoldrick v. Berwind-White Coal Co., 309 U. S. 33 (1940), it is probable that litigants will again seek to rely heavily on a privileges and immunities argument.

${ }^{20}$ The nature of a license fee not charged for revenue purposes is an assessment of the cost of regulation against the object regulated. It is therefore an incident of the police power and unless expressly authorized in the form of a revenue-producing fee it must bear a reasonable relation to the cost of regulation. A court, however, will not examine mathematically the exact allocation of cost on any accounting basis, but will give a presumption of validity to the assessment charged as a fee unless it can be shown that the charge has no relation to the cost at all. See In re opinion to the House of Representatives, 5 A. (2d) 455 (R. I. 1939); I CoOLEY, TAxarion (4th ed. 1924) 527; ct. Ex parte Holt, 74 Okla. 226, I78 Pac. 260 (I918); Atkins v. Philips, 8 So. 429 (Fla. 1890).

32 Barker Bros. v. City of Los Angeles, ro Cal. (2d) 603, 76 P. (2d) 97 (1938); of. City of Chicago v. Nechter, 183 Ill. I04, 55 N. E. 707 (1899).

${ }_{22}$ Pierson v. City of Seattle, IIg Wash. 217, 90 P. (2d) 1020 (1939); see also S. S. Kresge Co. v. Couzens, infra note 44 .
} 
or definitely directed against one group of persons for the private advantage of another and without any real relation to the public interest. The fact that the ordinance may in operation work to the advantage of one product or method of doing business and to the disadvantage of another, is of no legal consequence if the public interest in the exercise of the local police power presents a reasonable relation to the subject matter of the regulation. Here, as in any local law adopted pursuant to an implied power, the question of reasonableness is one of law.

The best known contemporary local tax ordinances having barrier effects are undoubtedly the local tax laws directed against chain stores. These ordinances have been adopted in a variety of forms. They have been based in some instances on a classification of business according to its gross revenue, whether received from business done within or without the city. ${ }^{23}$ Some have been graduated according to the number of units in the whole chain operating within the city, ${ }^{24}$ or in some situations the number of units operating in the system, wherever situated. ${ }^{25}$ Others, with an eye to the "serve yourself" systems, have been based upon a classification of the method by which particular chain store operators conduct their business. ${ }^{26}$ In any case, these ordinances have usually been designed, more or less frankly, to equalize the positions of the single-store dealer and the chain operator. They are practically all revenue measures as distinguished from police power license fee exactions. They, therefore, involve either a constitutional power to tax or an express legislative delegation of the power to raise revenue by taxation or occupational license fees.

In these cases three general problems, in addition to the obvious one of the existence of the power to tax for revenue purposes, have been considered. Since a tax directed against a chain store business must involve a classification in order to reach the desired subject, the relation of the classification adopted in the local ordinance, as compared to the differentiation made for tax purposes by state legislation, creates a problem. A further problem exists by virtue of the fact that any classification for the purpose of a revenue tax must be non-discriminatory and based on a reasonable difference in fact between the classes taxed and those not taxed, so that the tax law may have a uniform operation. Finally, although the power to tax is granted in unlimited form and with no restriction as to amount, nevertheless, the power to tax does not carry with it the power to prohibit a lawful business. Any tax legislation, therefore, must not in its operation be confiscatory.

As a general rule it has been held that a city has no power to adopt a basis of classification for tax purposes different from that which has been established by the state itself. If, on the other hand, the state has made no classification as to the subject matter to be taxed, then the local action will be upheld without reference to any state system. In some cases, the courts, in order to sustain the municipal law,

${ }^{23}$ City of Atlanta v. Georgia Milk Producers Confederation, 200 S. E. 7r2 (Ga. 1938).

${ }^{34}$ Kroger Grocery and Baking Co. v. City of St. Louis, 34I Mo. 62, I06 S. W. (2d) 435 (1937).

${ }^{25}$ Great A\&P Tea Co. v. City of Columbus, 189 Ga. 458, 6. S. E. (2d) 320 (1939); City Cauncil of Augusta v. Southern Grocery Stores, Inc., 189 Ga. 6I8, 7 S. E. (2d) I8I (r939).

${ }^{20}$ So of the Camden ordinance described in note 37 , infra. 
have gone rather far to establish a distinction between the state and local classifications of the subject matter of the tax. The ordinance of St. Louis, Missouri, providing for graduation of a license-fee tax according to the number of stores, is an example of an ordinance invalidated because of its relation to the classification established by state law. The state law had provided for local authority to tax and regulate the occupation of merchants and manufacturers and to graduate the amount in proportion to the sales made by the merchant or manufacturer during the year next preceding any fixed date. Considering the validity of the ordinance in the case of Kroger Grocery and Baking Co. v. City of St. Louis, ${ }^{27}$ the Supreme Court of Missouri held that the state law with respect to the method of classification for the purpose of a license was mandatory and not directory, and the local method of classification inconsistent therewith.

Other similar examples may be cited. A power to tax in proportion to sales has been held not to authorize a tax based on the floor space used in the business. ${ }^{28}$ So also has the power to tax single occupations been held not to authorize a local ordinance attempting their subdivision into various phases; thus the business of contractors generally, as provided by state law, cannot be divided by local ordinances into the trades of brick mason, plastering contractor, roofing contractor, electrical contractor, etc. ${ }^{29}$

On the other hand, in the case of Fredericksburg v. Sanitary Grocery $\mathrm{Co}^{30}$ the court held valid a local classification based on the number of stores in excess of one, as compared to the state law authorizing the tax but making no such classification. The court held that the city had not, by its local ordinance, attempted a subdivision of the class created by the state, but that it had created the entirely new classification of chain store merchants. In this case also, it is interesting to note, the court invoked, as against the charge of discrimination, the principle that the party assailing the classification must show that the business discriminated against is precisely the same as that included in the class which is alleged to be favored. Further examples of the validity of a local classification, in the absence of a controlling state classification, are Bradley v. Richmond, ${ }^{31}$ Williams v. Bolling Green, ${ }^{32}$ and Safeway Stores v. Portland..$^{33}$ In the Safeway Stores case, charter authority to grant licenses with the object of raising revenue or of regulation or both for any and all lawful acts, things, or purposes, and to fix by ordinance the amount to be paid therefor and the bases of revocation, was held sufficient to sustain an ordinance imposing an annual license fee of $\$ 50$ on each store of a chain in excess of 20 , whereas a single store was obliged to pay only $\$ 6$.

It is a well-settled principle that the operation of a local tax law as a revenue measure must be uniform on all persons in the same position. ${ }^{34}$ As a corollary to

\footnotetext{
${ }^{27}$ Supra note 24 .

${ }^{28}$ Kansas City v. J. I. Case Threshing Machine Co., 337 Mo. 913, 87 S. W. (2d) 195 (1935).

${ }^{20}$ Norfolk v. Grifin Bros., 120 Va. 524, 9x S. E. 640 (1917).

${ }^{30}$ I90 S. E. 318 , I10 A. L. R. II95 (Va. 1937). ${ }_{2127}$ U. S. 477 (1913).

$s_{22} 254 \mathrm{Ky}$. Ir, 70 S. W. (2d) 967 (I934).

${ }^{34}$ McQuilin, Municipal Corporations (2d. ed. I928) $\$ 2540$.
} 
this principle, any classification for the purpose of taxation must bear a reasonable relation to the facts and not arbitrarily discriminate between individuals identically situated. $^{35}$ It has been contended in several of the chain store tax cases that singling out the chain stores for the purpose of taxation is an unconstitutional discrimination against them as an ordinary means of business, not essentially different from any other method of selling. It has been generally held, however, as against this contention, that the different method of doing business is a sufficient differentiating basis for the purpose of classification. Thus in the Safeway case this objection was overruled by pointing out that: ${ }^{36}$

There is a real, recognized difference between a business carried on in one store and a business operated by means of a chain of stores. Whether it is wise or expedient based upon such difference to classify such chain stores in a class by themselves for the purpose of levying a license tax is, as we understand, a legislative question to be determined by the lawmakers.

A notable exception to this view is the opinion of the court in the case of Great A\&P Tea Co. v. Board of Commissioners of Camden, N. J.7 The Camden ordinance, it is known, was directed against the supermarket. It was there held that the imposition of a tax for revenue purposes upon self-service markets, as distinguished from markets in which goods were sold by clerks, was an arbitrary discrimination between persons engaged in the same business merely because one 'merchant chose a method of making sales which another did not use. The leading case sustaining chain store taxation by the state was distinguished in these words: $:^{38}$

The classification in question has not the slightest resemblance to classification predicated upon a desire to adjust competition or economic inequalities between merchants sustained in Great Atlantic and Pacific Tea Co. v. Grosjean.

Similar to the chain store tax situation are other revenue taxes assessed on a basis intending to discriminate against non-residents in favor of local dealers. While some classification on this basis is permissible in order to equalize the tax burdens between residents and non-residents doing business within the city, nevertheless, the distinction must not reach the point of placing the non-resident at a disadvantage. If so, it will be invalidated as an arbitrary classification.

The Camden supermarket case, already considered on the point of classification, affords as well a good example of an ordinance condemned because confiscatory. The tax imposed in that case was $\$ 10,000$ per year with a provision for a fine of $\$ 200$ or

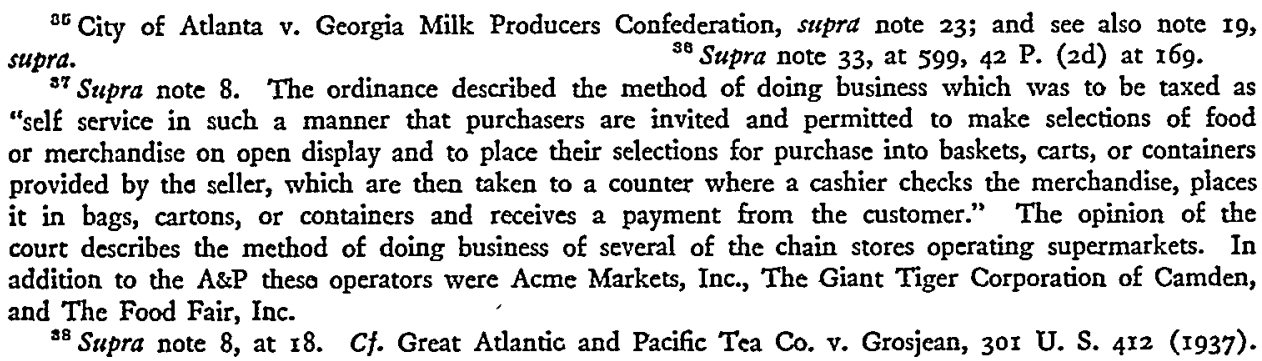


imprisonment not exceeding 90 days or both upon a conviction for violation of the ordinance. In determining the question of validity the court admitted and considered evidence as to the matters presented to the city council at a public hearing held before the adoption of the ordinance. The court also observed that while there was no limit on the amount of the tax which the city could levy, on the basis of the present rate of profit a business of $\$ 19,000$ a week would be required to meet the tax and none of the stores in the chain did any such amount of business. ${ }^{30}$ An ordinance of Augusta, Georgia, was also recently invalidated on the ground that it was unreasonable, arbitrary and confiscatory. The court held that the ordinance was not discriminatory as a violation of the uniformity rule, but that it was confiscatory as amounting to a destruction of a lawful business by use of the taxing power. ${ }^{40}$

Approach to the matter of confiscatory taxation from the point of view of reasonableness is to be found in the case of Great A\&P Tea Co. v. City of Columbus. ${ }^{41}$ The court said: ${ }^{42}$

Legislative powers conferred by charter provisions upon a municipality are not to be measured by the more extensive powers of the State legislature. . . O One requirement of all municipal ordinances is that they must be reasonable, and the courts must declare void an ordinance found unreasonable. . . This record does not present a case where the city has attempted under its police power to regulate the business affected by the tax ordinance.... While the city produced evidence which tended to show that the increase of chain stores in Columbus had had the effect of driving a much larger number of independent stores out of business, yet such evidence could not possibly illustrate any issue which the court is called upon to decide in the present case.... We do not mean to imply, however, that the receipts and the profits of the store, standing alone, although the tax completely consumes such profits, will suffice to show that the tax is unreasonable and void. But proof that the tax consumes the entire profits of the stores, coupled with evidence of the prevailing conditions in the city as a whole, showing that these profits are equal to the average in similar businesses, will demand a finding that the ordinance is unreasonable.

Thus although the power to tax is expressly granted, the above limitation on the manner of its exercise presents a question for judicial inquiry into a kind of "reasonableness" usually permissible where the ordinance does not follow a specific formula prescribed by statute but represents in effect a choice of means. As previously indicated, the question of the reasonableness of ordinances as an exercise of existing delegated power constitutes a second legal principle to be considered in weighing the legality of municipal barrier legislation. The doctrines adhered to by the courts in the administration of this principle are these: If an ordinance is adopted pursuant to a specific delegation of power from the legislature and precisely carries into effect the power granted, the local law will be accorded the same presumption of validity as is the state law itself; judicial inquiry into the reasonableness of the ordinance is precluded. The only matter open for judicial review in such a case is the

${ }^{39}$ See digest of brief for the city in the case of The Great A\&P Tea Co. v. Atlantic City, N. J., in the New Jersey Supreme Court, (1939) 4 Municipal Law J. 21.

${ }^{10}$ City Council of Augusta v. Southern Grocery Stores, Inc., supra note 25.

4I Supre note 25 .

${ }^{42}$ Id. at $466,468,470,6$ S. E. (2d) at $324,326$. 
question of the existence of local power to adopt the ordinance and that of constitutionality or conformity to general state law. If, on the other hand, the ordinance is adopted pursuant to implied local power or represents a choice of means for invoking an express power, then the reasonableness of the ordinance is a justiciable question. ${ }^{43}$ The judicial inquiry in this connection is a matter of determination of fact from the nature of the ordinance as it is drawn and from evidence which may be presented as to its operation and effect.

In no case does the court admittedly consider the motive of the council in adopting an ordinance, aside from a substantiated charge that the ordinance is arbitrary, capricious and an abuse of power. ${ }^{44}$ It is settled beyond any possibility of dispute that the matter of the wisdom or the policy of a local law, as well as any other legislative act, is a matter for the exclusive determination of the legislative body and not for the courts. ${ }^{45}$ For this reason the particular problem considered here, the use of an existing local power for the purpose of erecting barriers to free markets, is many times beyond judicial scrutiny. As a practical matter, however, the economic effect and operation of an ordinance may be proved without examination of the motive for its adoption. Furthermore, if an ordinance can be shown to have a particular unsound or undesirable effect in operation, it is certainly permissible to show that that effect was the one intended by the council. ${ }^{40}$ Consequently, it is frequently permissible and advisable to present evidence of the intention of the council and of the interests actually involved in the adoption of an ordinance, not for the purpose of impeaching its validity, but for the purpose of substantiating the attack based on some other ground. ${ }^{47}$

Judicial administration of the requirement of reasonableness in the case of regulatory as distinguished from tax measures is typified by instances concerning legislative favoritism in products and method of doing business. It is arguable, of course, that the sale of articles by the use of vending machines requires a peculiar type of regulation in order to insure against the sale of tobacco to minors and to guard against possible abuses resulting from the automatic feature of the sale. It is generally conceded that even a prohibitory regulation against the use of vending machines for certain purposes is valid. For instance, in the City of Red Cloud,

\footnotetext{
is Note r8, supra.

" S. S. Kresge Co. v. Couzens, 287 N. W. 427 (Mich. 1939); see also N. J. Good Humor v. Board of Comm'rs of Bradley Beach, II A. (2d) II3 (N. J. I940): "It is therefore evident that the challenged municipal action was dictated by a purpose to shield the local shopkeepers from lawful competition, and thus to serve private interests in contravention of common rights; and so it must be condemned as an abuse of the police power, and therefore ultra vires."

4 Thus it is said in Kroger Grocery and Baking Co. v. City of St. Louis, supra note 24, at 72, 106 S. W. (2d) at 438: "It is the tendency of commerce to magnify the importance of the quantity of trade; of society (we use the term in its broad sense) to magnify the importance of life, liberty, human happiness, and the quality of men. Motives attending the enactment of legislation in the furtherance of either objective may be most creditable and when on proposed legislation the two interests conflict, it is for the legislative branch of government, acting within its proper scope, not the judiciary, to choose between the conflicting values and determine the policy of the law. We deal only with the power of the city of St. Louis, not the expedience, wisdom, or justness of the license imposed."

${ }^{10}$ Southern Linen Supply Co. v. City of Corbin, 272 Ky. 787, II5 S. W. (2d) 321 (1938).

${ }^{4}$ See note 44, supra.
} 
Nebraska, an ordinance prohibiting the operation of vending machines for the retailing of gasoline was held valid. ${ }^{48}$

On the other hand, the City of Chicago was unsuccessful in its attempt to exclude paper containers from the local market area by invocation of the police power relating to public health. It was seriously contended that the paper containers were unsanitary and as a matter of fact liable to contaminate the milk. The ordinance was sustained against attack by the company producing the container-making machinery and by the manufacturer of the containers themselves on the ground that these persons had no proper interest in the application of the ordinance, as it did not operate directly on them but rather on the consumer of the paper bottles. ${ }^{40}$ Upon attack by a milk distributor, however, seeking approval by the Board of Health of the distribution of its product in the paper containers, the ordinance was invalidated as an unreasonable exercise of local police power, not shown to be properly related to the protection of public health. ${ }^{50}$

The problem of the relation of local tax measures to interstate commerce is essentially not different from the general relation of state laws to the same subject. For this reason no attempt will be made here to do more than indicate the parallel situation. ${ }^{51}$ The recent decision of Best \& Co. v. Maxwell ${ }^{52}$ points out that the commerce clause of the United States Constitution forbids any discrimination against an interstate transaction. In that case the statute required a $\$ 250$ license of a nonresident merchant displaying goods for sale by sample in any hotel room or temporary quarters whenever he did not maintain a regular place of business in North Carolina. The Court interpreted the recent decision of McGoldrick v. BerwindWhite Coal Mining $\mathrm{Co}^{63}$ as authorizing local sales taxes on interstate transactions only where the tax did not operate to discriminate against the out-of-state dealer. Municipalities as well as states have, in innumerable instances, enacted local tax measures for the purpose of discouraging out-of-state dealers doing a direct sales business by means of canvassers or drummers. ${ }^{54}$ While Robbins v. Shelby Taxing District ${ }^{55}$ has, by the Berwind-White case, been limited strictly to the situation of a fixed discriminatory license tax, nevertheless, the rather unrealistic distinction between canvassers and peddlers which had been made since the Robbins decision seems still to obtain. ${ }^{66}$ The general tenor of the Berwind-White case might be interpreted as a resort to a practical test of discrimination, so as to sustain a tax on an interstate transaction provided it appears to be an equalizing measure and not a discriminatory effort. Applied in the particular case to a transaction after an inter-

${ }^{18}$ Hawkins v. City of Red Cloud, r23 Neb. ${ }_{487}, 243$ N. W. 43I (1932).

${ }^{40}$ Ex-Cell-O Corp. v. City of Chicago, supra note 9.

${ }^{\text {bo }}$ Fieldcrest Dairies, Inc. v. City of Chicago, supra note 9.

${ }^{51}$ Cf. note 19, supra.

${ }^{52} 3$ II U. S. 454 (1940).

Es 309 U. S. 33 (1940).

"In McGoldrick v. Berwind-White Coal Mining Co., stpra note 53, the Court noted that several hundred such ordinances are in effect. See the Robbins case, stpra note 19, and Real Silk Mills v. City of Portland, 268 U. S. 325 (1925).

${ }^{65}$ Stipra note I9.

${ }^{58}$ Singer Sewing Machine Co. v. Brickell, 233 U. S. 304 (1914); Wagner v. Covington, 251 U. S. 95 (1919). 
state transit, its principles might easily be extended to a transaction preceding shipment. ${ }^{57}$

Indeed, the fundamental principle implicit in not only the Berwind-White case but also South Carolina Highway Department v. Barnwell Brothers ${ }^{58}$ may be stated in terms of an underlying doctrine or approach which applies equally to judicial examination of local legislation affecting non-residents, regardless of the federal constitutional question involved in state or local legislation affecting interstate commerce. In the Berwind-White case is the statement: ${ }^{59}$

Lying back of these decisions is the recognized danger that, to the extent that the burden falls on economic interests without the state, it is not likely to be alleviated by those political restraints which are normally exerted on legislation where it affects adversely interests within the state.

This statement might easily be formulated into a generalization as to the tenor of judicial inquiry wherever a problem of geographical representation and legislative action is presented, provided, of course, a proper basis for judicial action is laid. Thus enlarged, the principle would be applicable to the problem of the effect on non-residents of local laws having no interstate aspect whatsoever. It may easily be said that roughly speaking such a situation presents the same danger of local legislative action affecting extra-mural interests to which it is in no way responsible or responsive. To be sure, the municipality is a creature of the state and a measure of control may be exerted by resort to the state legislature. But with respect to a matter of local concern in a home-rule jurisdiction no state legislative power exists, and, practically speaking, such as may exist in non-home-rule states is many times inconsequential or ineffective. The courts should have this broad precept in mind when passing on the legality of a local ordinance with respect to its effect on nonresidents, whether they be within or without the particular state.

At least one instance is recorded of judicial invalidation of an ordinance found upon proof to be so administered as to operate as an effective prohibition against a non-resident doing business within the municipality. An occupational license tax for revenue purposes was duly authorized as applied to a linen-towel service business. $^{60}$ The tax for the privilege of conducting such a business within the municipality by any person was $\$ 200$. No provision in the ordinance itself disclosed any discrimination or even difference in its application to residents and nonresidents. One company located outside the city of Corbin, Kentucky, conducted a business of this type servicing several nearby municipalities. The $\$ 200$ fee was exacted from it and the company brought suit in the Kentucky courts complaining of the ordinance. On the trial the plaintiff showed that the license tax not only would so operate as to absorb more than the profit from his business done within the City of Corbin, but also that the only resident competitor likewise subject to the ordinance was charged but $\$ 40$ for his license fee. The resident operator testified,

\footnotetext{
${ }^{67}$ Lockhart, State Tax Barriers to Interstate Trade (1940) 53. H^rv. L. REv. 1253, 1275.

${ }^{68} 303$ U. S. I77, I85 (I938).

${ }^{50}$ Supra note 53 , at 47, n. 2.

${ }^{-0}$ Southern Linen Supply Co. v. City of Corbin, supra note 46.
} 
moreover, that the $\$ 200$ fee would amount to more than any of the profits which he made from the business. Fees charged by the neighboring municipalities were about \$25. The court, in allowing the injunction against the enforcement of the ordinance, held not only that the fee exacted was confiscatory but also that it had been proved by the evidence that the ordinance was passed to prohibit the business of a non-resident.

An Illinois sustainment of an ordinance licensing and regulating automatic vending machines, though the law required that licensees be either residents or maintain a business address in the city, ${ }^{61}$ introduces the problem of non-resident discrimination in regulatory ordinances adopted pursuant to the police power. The reported decisions are in hopeless conflict. Again the problem involves the attempt to exclude non-residents, the closely related problem of the attempt to exercise extra-territorial power, or an attempt by a local law to regulate a matter of interstate commerce. Many cases indicate no distinction between the revenue or police power purposes of a local law and most license ordinances are phrased in such a way as to invoke either or both sources of local power. A distinction does exist in that a revenue power may be invoked for the purpose of its resultant economic regulatory effect whereas an implied police power may not be employed to produce revenue as such, since power to tax must be express. Since the regulatory aspect is the important element here, the distinction should not be of great significance except in so far as the necessity for express authority to enact a revenue tax suggests a more limited scope of extra-mural impact as compared to the broad possibilities from exercise of implied police power. A rational approach should allow the local measure to stand, in spite of an incidental effect on these three phases of geographical limitation, as a police regulation if there is a reasonable relation in fact between the ordinance and local health, morals, safety, or general welfare, or as a revenue tax if it is expressly authorized and is not discriminatory or confiscatory.

Many decisions fail to take this rational view and unnecessarily restrict and hamper the scope of local ordinances. It has been held that a city has no power to require a non-resident to pay a tax or license fee for the use of a motor vehicle within the city limits. ${ }^{62}$ In C.D. Kenny Co. v. Town of Brevard, ${ }^{03}$ an ordinance taxing wholesale merchants, not otherwise taxed, who used city streets for delivery of goods by truck was held invalid and discriminatory as between resident and nonresident wholesale merchants. The court said: ${ }^{\text {s4 }}$

The erection of trade barriers between cities and towns by the power of taxation may not be extended beyond constitutional and statutory limits.

${ }^{a 1}$ Larson v. City of Rockford, 37 I Ill. 44x, 2 I N. E. (2d) 396 (1939).

${ }^{62}$ City of Flora v. Borders, 342 Ill. 208, 173 N. E. 784 (r930). Contra: Johnson v. City of Paducah, $x_{47}$ S. W. (2d) $72 \mathrm{I}$ (Ky. x94I); but see Davis v. Pelfrey, 147 S. W. (2d) 723 (Ky. 194I) (distinguishing the Johnson case to reach an opposite result).

${ }^{63} 217$ N. C. 269 , 7 S. E. (2d) $54^{2}$ (1940); see, however, Sivertsen v. City of Menlo Park, rog P. (2d) 928 (Cal. 194I).

6e Id. at 273,7 S. E. (2d) at 544 . 
But on the other hand, a municipality does have the power to regulate the sale and distribution of food and to provide for its inspection in the interest of public health. ${ }^{65}$ In the exercise of this power, an ordinance requiring a license of every vehicle used for the storage or carrying of food in the city except those delivering from duly licensed food-dealing establishments was held equally applicable to both residents and non-residents. ${ }^{66}$ Some courts have looked with favor upon ordinances requiring a license tax from a person doing business by means of motor vehicle within the municipality where the operator located outside the city conducts a regular system of delivery to customers within. ${ }^{67}$ It has been suggested, however, that in California an ordinance imposing a tax on vehicles should be made a constituent part of the general business license ordinance and not a separate ordinance taxing motor vehicles. ${ }^{68}$

In general it may be said that no discrimination under police or taxing power may be directly made against non-residents as an end in itself. ${ }^{69}$ Yet wherever any ordinance relates to the nature of the business transacted or the manner of conducting business within the municipality, and that business by virtue of either its character or the manner of its conduct requires special regulation, equalizing regulations against non-residents may properly be made. ${ }^{70}$

The exercise of police power by a municipality must in the absence of an express delegation from the legislature be restricted to the territorial limits of the city. The problem of the non-resident vendor who brings food products manufactured outside the city within the local territory for sale has therefore perplexed the municipalities as to means of properly protecting the consuming public by insuring that those products are pure, unadulterated, and fit for human consumption. In the case of a bakery located outside the city limits supplying local stores with products for sale to the local inhabitants, a move to apply the local ordinance authorizing the city health officer to inspect bakeries and to charge an inspection fee was held void as an attempt to exercise extra-territorial jurisdiction. ${ }^{71}$ As already remarked, it would seem that the rational solution should call for a recognition of valid exercise of

\footnotetext{
${ }^{\circ 5}$ Food Stores, Inc. v. City of Tulare, 12 Cal. (2d) 324,84 P. (2d) I40 (I938); Dorsa v. Santa Clara County, 23 Cal. App. (2d) 2r7, 72 P. (2d) 912 (1937).

${ }^{\circ 6}$ American Baking Co. v. City of Wilmington, 370 Ill. 400, 19 N. E. (2d) 172 (1938).

or The Emporium v. City of San Mateo, I77 Cal. 622, I7x Pac. 434 (1918). See also California Fireproof Storage Co. v. City of Santa Monica, 206 Cal. 714, 275 Pac. 948 (1928); Crosswell and Co. v. Bishopville, 172 S. C. 26 , 172 S. E. 698 (1934).

${ }^{8} 8$ Burke, Licensing the Transient Merchant-So What? (July I934) Western City MAG. 13-I4.

${ }^{60}$ Inz re Hart, 36 Cal. App. 627, 172 Pac. 6ro (1918); City of Watertown v. Rodenbaugh, 98 N. Y. Supp. 885 (1906); City of Saginaw v. Saginaw Circuit Judge, 106 Mich. 32, 63 N. W. 985 (I895).

${ }_{70}$ American Bakeries Co. v. City of Huntsville, 232 Ala. 612, 168 So. 880 (1936); American Bakeries Co. v. City of Sumter, I73 S. C. 94,174 S. E. 919 (1934), appeal dismissed, 293 U. S. 523 (1934) (higher fee charged non-resident justified as representing the higher cost of investigating his reputation, etc.). See also State ex rel. v. Wagner, 77 Minn. 483, 80 N. W. 633 (1899); Ex parte Wade, I46 S. W. 179 (Tex. Crim. App. I9I2); McQuillin, Municipar Corporations (2d ed. 1928) \$828. For a survey of the content of local ordinances adopted for the protection of the local public by requiring registration, photographs, fingerprints, bonds, and a period of time before issuance of a license to non-residents, see (1940) 5 MUNicipal LAw J. 47.

${ }_{71}$ Ex parte Ernest, 136 S. W. (2d) 535 (Tex. Crim. App. I940).
} 
local regulatory power if the extra-territorial effect of the regulation is reasonably incidental to necessary police power and the effect on residents and non-residents is the same. ${ }^{72}$ Perhaps the leading case in recent years agreeing with the rigid viewpoint of the Texas case above cited is that of City of Rockford v. Hey, ${ }^{73}$ holding that the City of Rockford had no power to subject ice cream factories located outside the city to inspection as a condition to the permission of the sale of ice cream within the city. In the Rockford case, however, it should be noted that the manufacturer was licensed by the state. ${ }^{74}$

A distinction readily suggests itself between non-residents doing business within the local area, who should naturally be subjected to the same regulations applying to inhabitants, and an attempt on the part of the city to exercise its powers outside the city limits. In either case, however, where the reasonable object of the ordinance is to protect the inhabitants, by an exercise of police power properly related to the end to be attained, and there is no evidence of an arbitrary attempt to exclude nonresidents or usurp power beyond the local jurisdiction, the ordinance should be sustained.

Operating most heavily against non-residents is the Green River type of ordinance aimed at the direct sales technique of the house-to-house canvasser. Adopted by over 400 cities from $x 935$ to 1939, this enactment is a simple prohibition of solicitors, peddlers, hawkers, and itinerant merchants from going upon the premises of private residences for the purpose of either peddling or soliciting without having been requested or invited by the occupants. In addition to the problems relating to interstate commerce and extra-territorial effect of such ordinances discussed above, these regulations involve the question of the validity of such a prohibition by the local authority. While the local authority, even under the police power, cannot prohibit a lawful business, it may declare to be a nuisance and prohibit any business or method of doing business which is in fact a public nuisance. A case can be made out sustaining the nuisance character of house-to-house sales methods; nevertheless, it is debatable whether or not this nuisance is public or private. The local police power to prohibit is naturally confined to public nuisances. The original Green River ordinance was sustained in the case of Town of Green River $v$. Bunger, ${ }^{75}$ but similar enactments have been invalidated in the states of Oklahoma, Florida, South Carolina, Virginia, Maryland, Georgia, and Nebraska. ${ }^{70}$ Because of

${ }^{72}$ See City of Norfolk v. Flynn, ror Va. 473, 44 S. E. 717 (1903). Accord: Wright v. Richmond County, I82 Ga. 65I, I86 S. E. 855 (1936); American Baking Co. v. City of Wilmington, supra note 66; State ex rel. Hogan v. Spencer, r39 Fla. 246, 190 So. 506 (1939); Langs Creamery, Inc. v. City of Niagara Falls, 23I N. Y. Supp. 368 (r928); Whitt v. Climm, 97 Cal. App. 13I, 274 Pac. 1039 (r929); Gilchrist Drug Co. v. City of Birmingham, 234 Ala. 204, 174 So. 609 (1937).

${ }^{73}$ Supra note 10.

74 Ibid. Accord: Grant v. Leavell, 259 Ky. 267,82 S. W. (2d) 283 (I935); Miller v. Williams, 12 F. Supp. 236 (D. Md. r935); State v. Minneapolis, 190 Minn. 138, 251 N. W. I21 (1933).

${ }^{78}$ Supra note 7. A recent case in accord is Ex parte Lewis, 147 S. W. (2d) 478 (Tex. Crim. App. I94I).

${ }_{70}$ See (1940) 5 MUNictpal Law J. 23, 46, 84, and cases collected in Report of the Committee on Ordinance and Ordinance Enforcement, in Municipalities aND THE LAW IN Action (Nat. Inst. Mun. Law Officers, I940). 
the debatable ground on which these ordinances are based their economic effect as market barriers may well be considered by the courts as well as by the local city council.

Finally, a form of local barrier law may be found in the general tendency in local affairs to give preference to local labor or local products in government purchases or construction. These ordinances have taken the form of direct residence or citizenship requirements and are generally free from any attack based on federal constitutional limitation. In New York it has recently been held that a three-year residence requirement to establish eligibility for local civil service employment is valid. ${ }^{77}$ In the conduct of local government business the municipality and the state alone are concerned. ${ }^{78}$

While it is beyond the scope of this discussion to propose any concrete solution for market-barrier evils arising from local legislation, it may be suggested that as a general rule the economic desirability of the local ordinances, in so far as they operate on local groups, may be safely left as a matter for the exclusive jurisdiction of the city council, which, at least theoretically, represents all interested and affected persons. In the case of local legislation which by design or effect sets up a tariff wall around a local marketing area to insulate it from traders from other parts of the country, a problem of importance to the national unity is presented and requires attention beyond that likely from the local enacting body. The courts in review of such local laws may be addressed upon matters of reasonableness, arbitrary classification, extra-territorial operation, or discrimination against interstate commerce, in accordance with the principles above illustrated. Wherever such judicial inquiry will prove ineffective, congressional action may in some measure be effective. On the other hand, a note of warning might well be sounded in view of the extensive literature which is rapidly growing up in this field, and in view of the intensive drive toward national unification of all economic resources as a defense measure. The study of the barrier effect of local as well as state legislation should not be allowed to develop into a witch hunt which would tend to distort and proscribe many forms of reasonable and necessary local equalizing laws, or necessary protective measures enacted in the course of the exercise of legitimate police power.

\footnotetext{
${ }^{77}$ Mullins v. Kern, 280 N. Y. 543, 20 N. E. (2d) 10 (I939).

${ }^{78}$ Patsone v. Pennsylvania, 232 U. S. 138 (I9I4); McAllister, Court, Congress and Trade Barriers (1940) I6 IND. L. J. $144,164-165$.
} 